\title{
Licochalcone A induces T24 bladder cancer cell apoptosis by increasing intracellular calcium levels
}

\author{
XINHUI YANG, JIANGTAO JIANG, XINYAN YANG, JICHUN HAN and QIUSHENG ZHENG
}

\begin{abstract}
Department of Pharmacology, Key Laboratory of Xinjiang Endemic Phytomedicine Resources of Ministry of Education, School of Pharmacy, Shihezi University, Shihezi, Xinjiang 832002, P.R. China
\end{abstract}

Received May 12,2015; Accepted May 3, 2016

DOI: $10.3892 / \mathrm{mmr} .2016 .5334$

\begin{abstract}
Licochalcone A (LCA) has been reported to significantly inhibit cell proliferation, increase reactive oxygen species (ROS) levels, and induce apoptosis of T24 human bladder cancer cells via mitochondria and endoplasmic reticulum (ER) stress-triggered signaling pathways. Based on these findings, the present study aimed to investigate the mechanisms by which LCA induces apoptosis of T24 cells. Cultured T24 cells were treated with LCA, and cell viability was measured using the sulforhodamine B assay. Apoptosis was detected by flow cytometry with Annexin V/propidium iodide staining, and by fluorescent microscopy with Hoechst 33258 staining. The levels of intracellular free calcium ions were determined using Fluo-3 AM dye marker. Intracellular ROS levels were assessed using the 2',7'-dichlorodihydrofluorescein diacetate probe assay. The mitochondrial membrane potential was measured using 5,5',6,6'-tetrachloro-1,1',3,3'-tetraethyl benzimidazole carbocyanine iodide. Furthermore, the mRNA expression levels of B-cell lymphoma (Bcl)-extra large, Bcl-2-associated $\mathrm{X}$ protein, Bcl-2-interacting mediator of cell death, apoptotic protease activating factor-1 (Apaf-1), calpain 2, cysteinyl aspartate specific proteinase (caspase)-3, caspase- 4 and caspase- 9 were determined using reverse transcription semiquantitative and quantitative polymerase chain reaction analyses. Treatment with LCA inhibited proliferation and induced apoptosis of T24 cells, and increased intracellular $\mathrm{Ca}^{2+}$ levels and ROS production. Furthermore, LCA induced mitochondrial dysfunction, decreased mitochondrial membrane potential, and increased the mRNA expression levels of Apaf-1, caspase-9 and caspase-3. Exposure of T24 cells to LCA also triggered calpain 2 and caspase- 4 activation, resulting in apoptosis. These findings indicated that LCA
\end{abstract}

Correspondence to: Professor Qiusheng Zheng, Department of Pharmacology, Key Laboratory of Xinjiang Endemic Phytomedicine Resources of Ministry of Education, School of Pharmacy, Shihezi University, Bei'er Road, Shihezi, Xinjiang 832002, P.R. China

E-mail: zqsyt@sohu.com

Key words: licochalcone A, reactive oxygen species, T24 cells, apoptosis, intracellular $\mathrm{Ca}^{2+}$ increased intracellular $\mathrm{Ca}^{2+}$ levels, which may be associated with mitochondrial dysfunction. In addition, the ER stress pathway may be considered an important mechanism by which LCA induces apoptosis of T24 bladder cancer cells.

\section{Introduction}

Natural herbal medicines have long been used to treat cancer. Biomedical research and cancer treatment clinical trials have provided evidence regarding the use of herbal medicines; therefore, they are increasingly being accepted as a complementary and alternative treatment (1). In addition, natural medicines have been reported to have an important role in human health, particularly certain well-studied plants, including Taxus chinensis (Taxus madia) (2), Radix Sophorae flavescentis (Sophora flavescens) (3), Alkanna tinctoria, Lithospermum erythrorhizon and licorice (Glycyrrhiza L) (4). Licorice is one of the most commonly prescribed herbs in Chinese Traditional Medicine, and has been used for $>2,000$ years. The effects of licorice have been reported on various diseases, ranging from microbial infection to cancer (5-7). However, since herbs usually contain numerous chemical compositions, the mechanism of action of these herbs is currently unclear. Recently, several chemical ingredients have been isolated and proved to contribute to the activities of licorice. The main bioactive constituents of licorice include triterpene saponins and various types of flavonoids (8).

Licochalcone A (LCA) is a chalcone compound isolated from licorice root (Radix Glycyrrhizae), which is known for its numerous biological activities, including anti-inflammatory (9) antimicrobial (10), antioxidant (11) and anticancer effects (12).

Apoptosis, or 'programmed cell death' (PCD), is a normal event that occurs in multicellular organisms (13). Previous studies have suggested that reactive oxygen species (ROS) have an important role in the mitochondrial apoptotic pathway (14), and have been shown to be involved in endoplasmic reticulum (ER) stress-induced apoptosis $(15,16)$. In addition, increases in intracellular $\mathrm{Ca}^{2+}$ levels may contribute to ROS accumulation and ER stress (17).

$\mathrm{Ca}^{2+}$, which is one of the most versatile second messengers, regulates various cellular functions, including contraction, secretion, metabolism, gene expression, cell survival and PCD (18). Calpains are $\mathrm{Ca}^{2+}$-activated non-lysosomal cysteine 
proteases, which have been reported to promote cysteinyl aspartate specific proteinase (caspase)- 4 activation during ER stress-induced apoptosis (19-21). Furthermore, it has been reported that LCA induces apoptosis in HepG2 hepatocellular carcinoma cells through induction of ER stress via a phospholipase C gamma 1-, $\mathrm{Ca}^{2+}$ - and ROS-dependent pathway (22).

Our previous studies have demonstrated that LCA may significantly increase ROS levels and induce apoptosis of T24 human bladder cancer cells (23). However, the underlying molecular mechanism remains unclear. The present study aimed to further elucidate the mechanism by which LCA induces apoptosis of T24 cells.

\section{Materials and methods}

Reagents. LCA (purity $\geq 98 \%$ ) was purchased from Zhongxin Pharmaceutical Group Corp., Ltd. (Tianjin, China). Roswell Park Memorial Institute (RPMI) 1640 medium was obtained from Gibco (Thermo Fisher Scientific, Inc., Waltham, MA, USA). Super neonatal bovine serum (NBS) was purchased from Hangzhou Sijiqing Biological Engineering Materials Co., Ltd. (Hangzhou, China). Annexin V/propidium iodide (PI) apoptosis kit was purchased from Nanjing KeyGen Biotech. Co. Ltd. (Nanjing, China). Molecular Probes 2',7'-dichlorodihydrofluorescein diacetate $\left(\mathrm{H}_{2} \mathrm{DCFDA}\right.$; Thermo Fisher Scientific, Inc.,), ethylene glycol tetraacetic acid (EGTA), Fluo-3 AM ester, and Hoechst 33258 were purchased from Sigma-Aldrich (St. Louis, MO, USA). BAPTA-AM was purchased from AAT Bioquest, Inc. (Sunnyvale, CA, USA).

Cell culture and treatment. The T24 human bladder cancer cells were purchased from the Cell Bank of the Committee on Type Culture Collection of the Chinese Academy of Sciences (Shanghai, China). The cells were maintained in RPMI 1640 medium supplemented with $10 \% \mathrm{NBS}(\mathrm{v} / \mathrm{v}), 100 \mathrm{U} / \mathrm{ml}$ penicillin and $100 \mu \mathrm{g} / \mathrm{ml}$ streptomycin at $37^{\circ} \mathrm{C}$ in a humidified atmosphere containing $5 \% \mathrm{CO}_{2}$. Cells were allowed to attach for $24 \mathrm{~h}$ prior to treatment. LCA was dissolved in dimethyl sulfoxide (DMSO) and diluted with fresh medium to achieve the desired concentration. The final concentration of DMSO did not exceed $0.2 \%$ in the fresh medium, and DMSO at this concentration is known to have no significant effect on cell viability.

Cell viability assay. Cell viability was measured using the sulforhodamine B (SRB) assay (24). Briefly, T24 cells were trypsinized and seeded into 96 -well plates at $1.0 \times 10^{5}$ cells $/ \mathrm{ml}$. Subsequently, the cells were exposed to LCA (0, 20, 40 and $80 \mu \mathrm{M}$ ) for $24 \mathrm{~h}$, followed by a further $24 \mathrm{~h}$ incubation in fresh medium. The T24 cells were then fixed with trichloroacetic acid and stained for $30 \mathrm{~min}$ with $0.4 \%$ (wt/vol) SRB (Sigma-Aldrich) dissolved in $1 \%$ acetic acid. Unbound dye was removed by four washes with $1 \%$ acetic acid, and protein-bound dye was extracted with $150 \mathrm{ml}$ DMSO for determination of optical density was detected at a wavelength of $490 \mathrm{~nm}$ using a Varioskan Flash 3001 plate reader (Thermo Fisher Scientific, Inc.).

Quantification of apoptosis by flow cytometry. Apoptosis was assessed using Annexin V-fluorescein isothiocyanate (FITC) and PI labeling, as previously described (25). Cells were treated with $0,20,40$ and $80 \mu \mathrm{M}$ LCA for $24 \mathrm{~h}$. Subsequently, the cells were washed twice with phosphate-buffered saline (PBS), and were resuspended in staining buffer containing $5 \mu \mathrm{l}(1 \mathrm{mg} / \mathrm{ml})$ PI and $5 \mu \mathrm{l}$ Annexin V-FITC. Double-labeling was performed at room temperature for $10 \mathrm{~min}$ in the dark prior to flow cytometric analysis. Cell staining was detected using a FACStar flow cytometer (BD Biosciences, Franklin Lakes, NJ, USA).

Determination of morphological alterations. Alterations in the nuclear morphology of apoptotic cells were observed by labeling the cells with the nuclear stain Hoechst 33258, and examining them under a fluorescent microscope. After treatment with 0, 20, 40 and $80 \mu \mathrm{M}$ LCA for $24 \mathrm{~h}$, the cells were fixed in formaldehyde (40 g/l) in PBS for $20 \mathrm{~min}$, followed by Hoechst $33258(10 \mathrm{mg} / \mathrm{l})$ staining for $30 \mathrm{~min}$ in the dark at $37^{\circ} \mathrm{C}$. Nuclear morphology was subsequently observed under a fluorescence microscope (MIC00266; Zeiss, Oberkochen, Germany) (26).

Detection of $\mathrm{Ca}^{2+}$ concentration. $\mathrm{Ca}^{2+}$ concentration was measured by Fluo-3 AM staining and microscopy. Briefly, T24 cells were incubated with or without $\mathrm{Ca}^{2+}$ chelators $(200 \mu \mathrm{M}$ EGTA and $10 \mu \mathrm{M}$ BAPTA-AM) for $1 \mathrm{~h}$ prior to $5 \mu \mathrm{M}$ LCA treatment for $24 \mathrm{~h}$. Subsequently, the cells were harvested and washed twice, and were resuspended in Fluo $3 \mathrm{AM}(5 \mu \mathrm{M})$ at $37^{\circ} \mathrm{C}$ for $30 \mathrm{~min}$. After washing three times, the stained cells were observed under a computer-assisted microscope (MIC00266; Carl Zeiss AG, Oberkochen, Germany) at an excitation wavelength of $488 \mathrm{~nm}$ and an emission wavelength of $525 \mathrm{~nm}$.

Detection of intracellular ROS levels. The intracellular levels of ROS in T24 cells were assessed using $\mathrm{H}_{2}$ DCFDA (27). Briefly, cells were incubated with $55 \mu \mathrm{M}$ LCA or with $10 \mu \mathrm{M}$ BAPTA-AM (a chelator of cytosolic $\mathrm{Ca}^{2+}$ ) for $1 \mathrm{~h}$ prior to LCA treatment. The treated cells were then washed in PBS and incubated with $30 \mu \mathrm{M} \mathrm{H}_{2} \mathrm{DCFDA}$ for $30 \mathrm{~min}$ at $37^{\circ} \mathrm{C}$. Fluorescence was detected using a fluorescent plate reader at 485/525 nm excitation/emission wavelengths (Varioskan Flash 3001; Thermo Fisher Scientific, Inc.) and data were expressed as median fluorescence intensity. The stained cells were then observed under a computer-assisted microscope (MIC00266; Carl Zeiss AG).

Measurement of mitochondrial membrane potential $(M M P)$. The MMP was assessed using a dual-emission potential-sensitive probe, 5,5',6, 6'-tetra-chloro-1, 1',3,3'-tetraethyl-imidacarbocyanine iodide (JC-1; KeyGen Biotech Co., Ltd., Nanjing, China). The ratio of red to green fluorescence of JC-1 depends solely on membrane potential, with a decrease being indicative of membrane depolarization (28). Briefly, the cells were exposed to $\operatorname{LCA}(0,20,40$ or $80 \mu \mathrm{M})$ for $4,8,16$ or $24 \mathrm{~h}$. Subsequently, the cells were loaded with $2 \mathrm{mg} / \mathrm{l} \mathrm{JC}-1$ at $37^{\circ} \mathrm{C}$ for $20 \mathrm{~min}$, and were analyzed using a plate reader (Varioskan Flash 3001; Thermo Fisher Scientific, Inc.).

Reverse transcription semiquantitative and quantitative polymerase chain reaction ( $P C R$ ). Total RNA was extracted from 
Table I. Polymerase chain reaction primer sequences.

\begin{tabular}{lll}
\hline Primer & \multicolumn{1}{c}{ Forward } & \multicolumn{1}{c}{ Reverse } \\
\hline GAPDH & CAAGGTCATCCATGACAACTTTG & GTCCACCACCCTGTTGCTGTAG \\
Bcl-xL & GCATATCAGAGCTTTGAACAGGT & TAGGTGGTCATTCAGGTAAGTGG \\
Bax & ACGAACTGGACAGTAACATGGAG & CAGTTTGCTGGCAAAGTAGAAAAG \\
Bim & CACATGAGCACATTTCCCTCT & AAGGCACAAAACCTGCAGTAA \\
Caspase-3 & CTGGACTGTGGCATTGAGAC & ACAAAGCGACTGGATGAACC \\
Caspase-4 & TGAACTGGAAGGAAGAGGAA & GCGGTTGTTGAATATCTGGA \\
Caspase-9 & CAGTGGGCTCACTCTGAAGACC & ACGCGTTACTGGCATTGAGG \\
Apaf-1 & TGGAATGGCAGGCTGTGGGA & TGCACTCCCCCTGGGAAACA \\
Calpain 2 & GCAGCCATTGCCTCCCTCAC & ACCTCCACCCACTCGCCGTA
\end{tabular}

GAPDH, glyceraldehyde 3-phosphate dehydrogenase; Bcl-xL, B-cell lymphoma (Bcl)-extra large; Bax, Bcl-2-associated X protein; Bim, Bcl-2-interacting mediator of cell death; Apaf-1, apoptotic protease activating factor-1.

T24 cells using TRIzol (Sangon Biotech Co., Ltd., Shanghai, China). RNA quality was determined using the A260/A280 ratio and $1.5 \%$ agarose gel electrophoresis. cDNA synthesis was performed using Moloney murine leukemia virus reverse transcriptase with a First Strand cDNA Synthesis kit (Fermentas; Thermo Fisher Scientific, Inc.). The synthesized cDNA was amplified by Riboloek Nase-free $\mathrm{ddH}_{2} \mathrm{O}(8 \mu \mathrm{l})$, template RNA (3 $\mu \mathrm{l})$, Oligo(dT)18 (1 $\mu \mathrm{l})$ to a final volume of $12 \mu \mathrm{l}$. Tubes were placed into the $\mathrm{C} 1000$ Thermal Cycler (Bio-Rad Laboratories, Inc., Hercules, CA, USA) at $70^{\circ} \mathrm{C}$ for $5 \mathrm{~min}$, following which $5 \mathrm{X}$ reaction buffer $(4 \mu \mathrm{l})$, Riboloek Nase Indihitor $(1 \mu \mathrm{l})$, dNTP M-M RT RTase $(1 \mu \mathrm{l})$ and RNase DEPC-treated water to a final volume of $20 \mu \mathrm{l}$ were added and incubated at $42^{\circ} \mathrm{C} 1 \mathrm{~h}$ for denaturation and $70^{\circ} \mathrm{C} 5 \mathrm{~min}$ for annealing. The synthesized cDNA was amplified by Oligo(dT) $)_{18}$, according to the instructions of a PCR Amplification kit (Fermentas; Thermo Fisher Scientific, Inc.). The PCR primers (synthesized by Sangon Biotech Co., Ltd.; presented in Table I) and their cycling conditions were set as indicated. The PCR reaction volume consisted of $12.5 \mu 1$ 2X PCR Master (Sangon Biotech Co., Ltd.), $3 \mu \mathrm{l}$ cDNA template and $0.5 \mu \mathrm{l}$ of each primer. The cycling conditions were as follows: Pre-denaturation at $94^{\circ} \mathrm{C}$ for $3 \mathrm{~min}$, with $30-35$ cycles of denaturation at $94^{\circ} \mathrm{C}$ for $30 \mathrm{sec}$, annealing for $30 \mathrm{sec}$, extension at $72^{\circ} \mathrm{C}$ and a final extension at $72^{\circ} \mathrm{C}$ for $10 \mathrm{~min}$, using a $\mathrm{C} 1000$ Thermal Cycler (Bio-Rad Laboratories, Inc.). The gene products were quantified using agarose gel electrophoresis (Biodee Biotechnology Co., Ltd., Beijing, China) and a Bio-Rad gel imaging system (Bio-Rad Laboratories, Inc.).

The quantitative PCR analysis was carried out according to the manufacturer's protocol of the Taqman One-Step PCR Master Mix (Applied Biosystems; Thermo Fisher Scientific, Inc.). Total cDNA $(2 \mu \mathrm{l})$ was added per $25 \mu \mathrm{l}$ reaction, alongside $0.5 \mu \mathrm{l}$ sequence-specific primers and $12.5 \mu \mathrm{l}$ SYBR Premix Ex Taq. All target gene primers and probes were purchased commercially (Sangon Biotech Co., Ltd.). Glyceraldehyde 3-phosphate dehydrogenase (GAPDH) was used as an internal control. The cycling conditions were as follows: Pre-denaturation at $95^{\circ} \mathrm{C}$ for $4 \mathrm{~min}$, denaturation at $95^{\circ} \mathrm{C}$ for $5 \mathrm{sec}$, annealing for $30 \mathrm{sec}$, extension at $72^{\circ} \mathrm{C}$ and a final extension at $72^{\circ} \mathrm{C}$ for $10 \mathrm{~min}$, using a Rotor-Gene Q Real time PCR machine (Qiagen China Co., Ltd, Shanghai, China). Relative expression levels of the target genes were calculated based on the $2^{-\Delta \Delta \mathrm{Cq}}$ method of relative quantification (29), according to the following equation: Relative expression level $=2$ (Cq value of GAPDH - Cq value gene of interest). The primer sequences are presented in Table I.

Statistical analysis. Data are presented as the mean \pm standard from at least three independent experiments. Data were evaluated by one-way analysis of variance followed by Student-Newman-Keuls test, uding Origin software, version 8.0 (OriginLab, Northampton, MA, USA). In all cases, $\mathrm{P}<0.05$ was considered to indicate a statistically significant difference.

\section{Results}

LCA induces cell apoptosis in T24 human bladder cancer cells. To examine cell viability in vitro, the SRB assay was used to determine the inhibitory effects of LCA on proliferation. A total of $24 \mathrm{~h}$ post-LCA treatment, LCA reduced the proliferation of T24 cells in a dose-dependent manner; the half maximal inhibitory concentration was $\sim 55 \mu \mathrm{M}\left(\mathrm{P}=4.3 \times 10^{-13}\right.$; Fig. 1A). Subsequently, it was investigated whether LCA was able to induce cell death through an apoptotic mechanism. Annexin V-FITC and PI double-labeling was used for the detection of phosphatidylserine externalization, a hallmark of early phase apoptosis. Compared with the control group, a high proportion of Annexin $\mathrm{V}^{+}$labeling was detected in cells treated with LCA, thus indicating that they were in the early phase of apoptosis $\left(\mathrm{P}=1.3 \times 10^{-5}\right.$; Fig. $1 \mathrm{~B}$ and $\left.\mathrm{C}\right)$. These results indicate that LCA significantly induced apoptosis in T24 cells.

LCA induces alterations in nuclear morphology. Typical apoptotic morphological alterations, as indicated by condensed nuclei and nuclear fragmentation, were apparent after exposure to $40 \mu \mathrm{M}$ LCA. Apoptotic nuclear alterations were markedly increased in the cells pretreated with $80 \mu \mathrm{M}$ LCA (Fig. 2).

LCA induces $\mathrm{Ca}^{2+}$ release. Following treatment of T24 cells with LCA, $\mathrm{Ca}^{2+}$ levels were significantly increased compared 


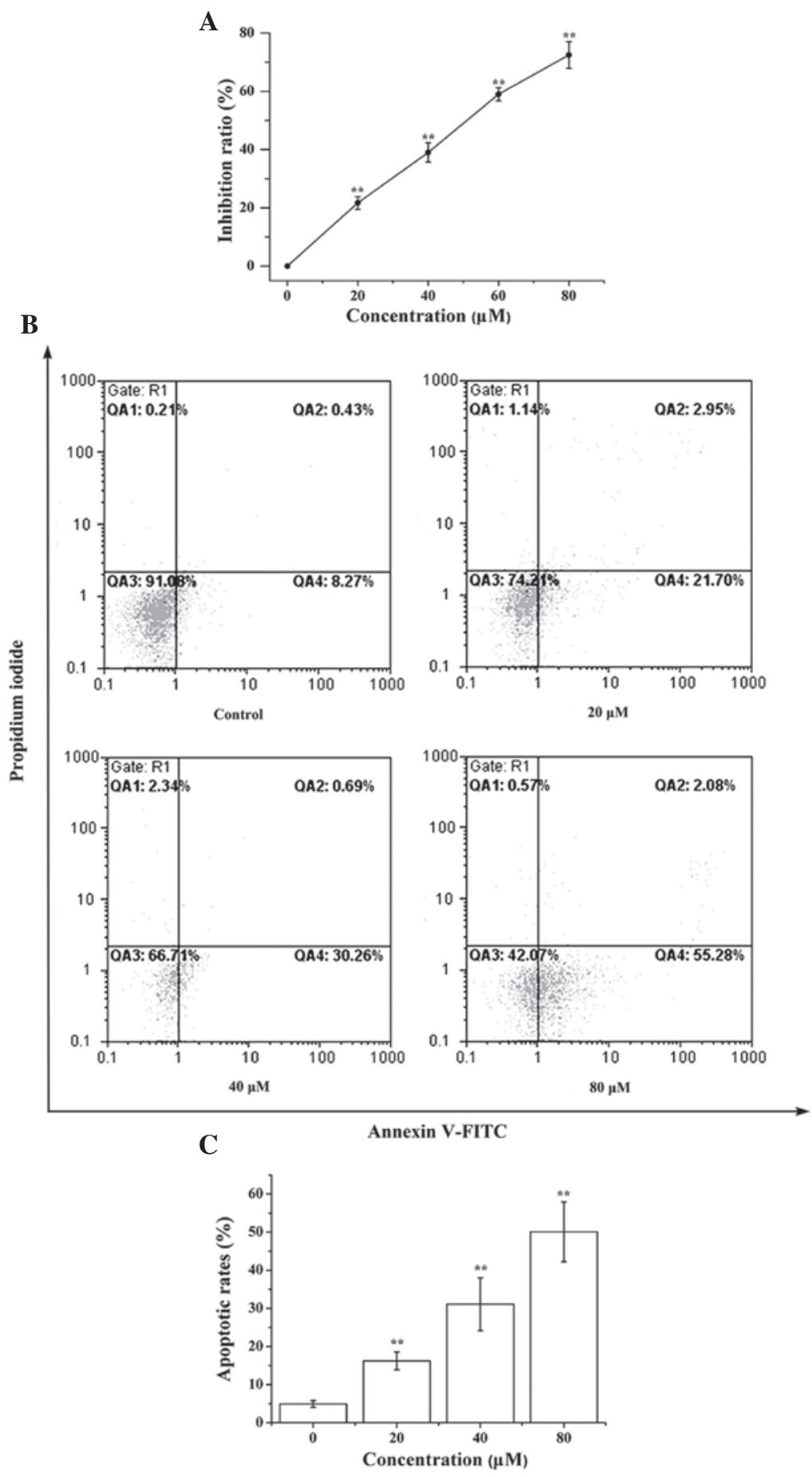

Figure 1. Licochalcone A (LCA) induced the apoptosis of T24 cells. (A) Effects of LCA on T24 cell proliferation and survival. The inhibitory ratio of LCA on cell proliferation was determined using the sulforhodamine B assay $24 \mathrm{~h}$ post-treatment $(0,20,40,60$ and $80 \mu \mathrm{M} \mathrm{LCA})$. (B and C) Cells were treated with 0, 20, 40 and $80 \mu \mathrm{M} \mathrm{LCA}$ for $24 \mathrm{~h}$, and the percentage of apoptotic cells was analyzed by flow cytometric analysis of Annexin V-fluorescein isothiocyanate (FITC)/propidium iodide double staining $(\mathrm{n}=3)$. Data are presented as the mean \pm standard deviation of three independent experiments. ${ }^{* *} \mathrm{P}<0.01$ compared with the untreated control group.

with the control group. These results indicate that LCA promoted $\mathrm{Ca}^{2+}$ release in a time-dependent manner (30 min, $\mathrm{P}=4.3 \times 10^{-13} ; 2$ h, $\mathrm{P}=1.2 \times 10^{-5} ; 4$ h, $\mathrm{P}=0.0084$; Fig. 3A). In order to investigate whether LCA could induce an increase in cytosolic $\mathrm{Ca}^{2+}$ through extracellular or intracellular $\mathrm{Ca}^{2+}$ pools, the T24 cells were pretreated with EGTA (an extracellular $\mathrm{Ca}^{2+}$ chelator) and BAPTA-AM (an intracellular $\mathrm{Ca}^{2+}$ chelator). EGTA and BAPTA-AM significantly suppressed
LCA-induced $\mathrm{Ca}^{2+}$ release $\left(\mathrm{P}=1.9 \times 10^{-6}\right.$ and $\mathrm{P}=2.2 \times 10^{-6}$, respectively; Fig. 3B). Furthermore, BAPTA-AM could attenuate LCA-induced apoptosis, whereas EGTA had no inhibitory effects on apoptosis (Fig. 3C). Collectively, these results indicate that LCA mainly induced release of intracellular $\mathrm{Ca}^{2+}$ to promote apoptosis.

To determine whether cytosolic $\mathrm{Ca}^{2+}$ release is a signal leading to ROS accumulation in LCA-induced apoptosis, 

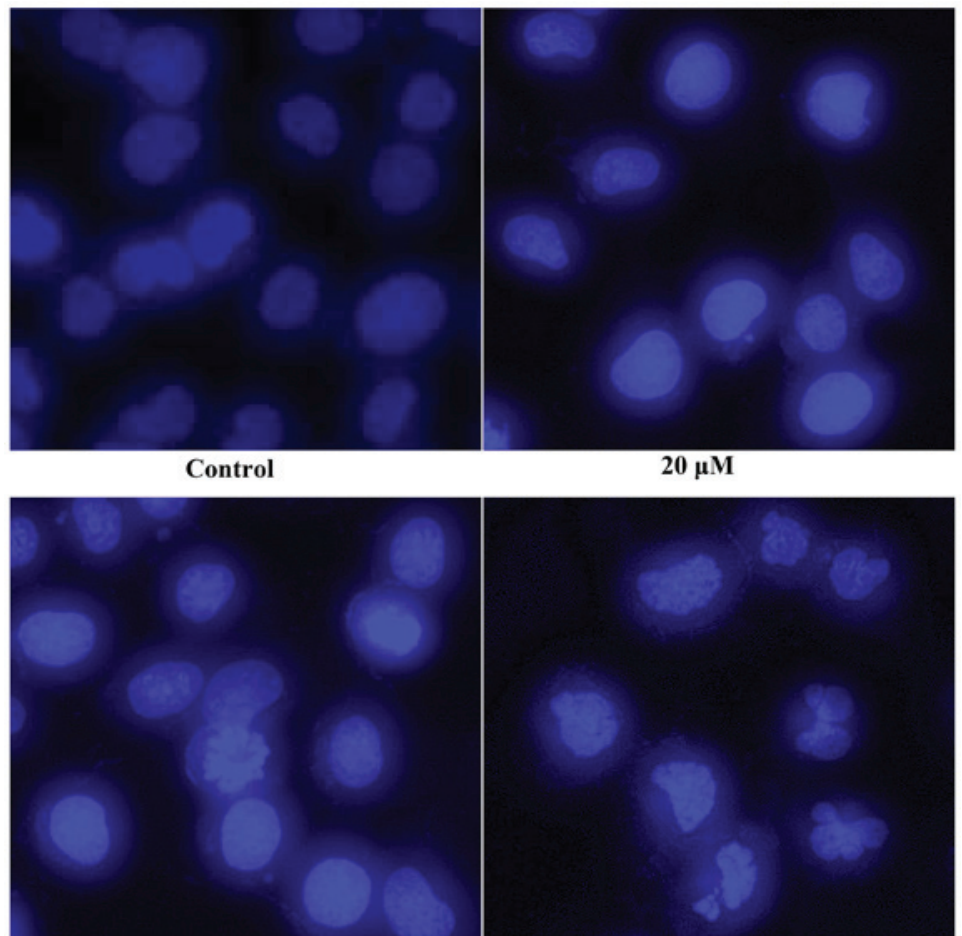

$40 \mu \mathrm{M}$

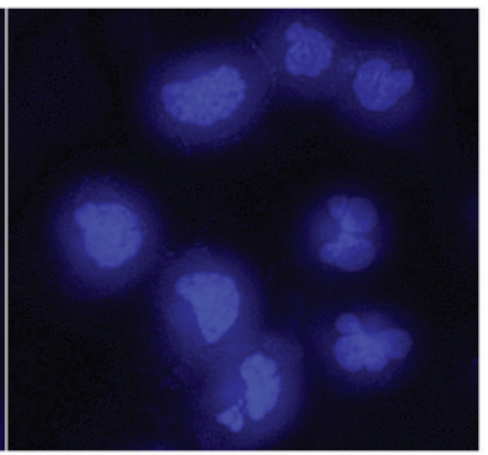

$80 \mu \mathrm{M}$

Figure 2. Morphologic alterations in T24 cells. Cells were incubated with 0, 20, 40 and $80 \mu \mathrm{M}$ licochalcone A for $24 \mathrm{~h}$ and stained with the DNA-binding fluorochrome Hoechst 3258 (magnification, x400).

A

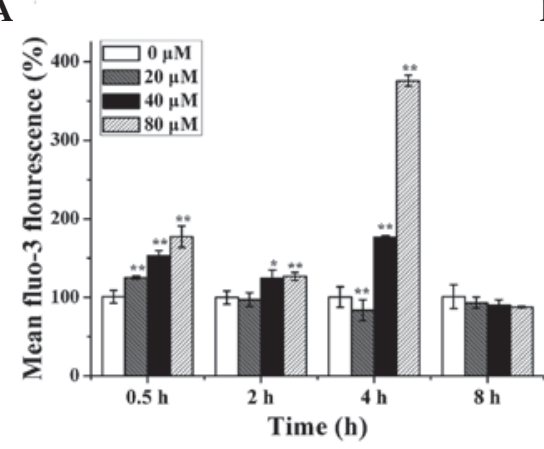

C

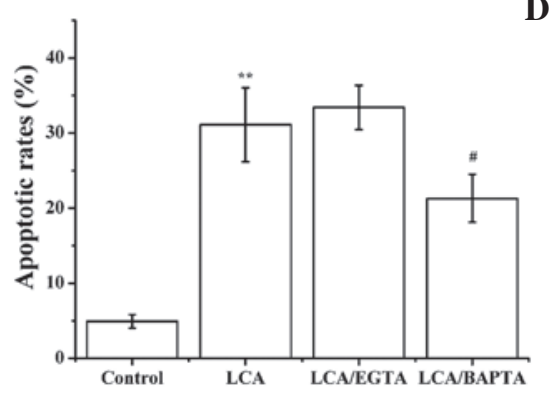

B

D
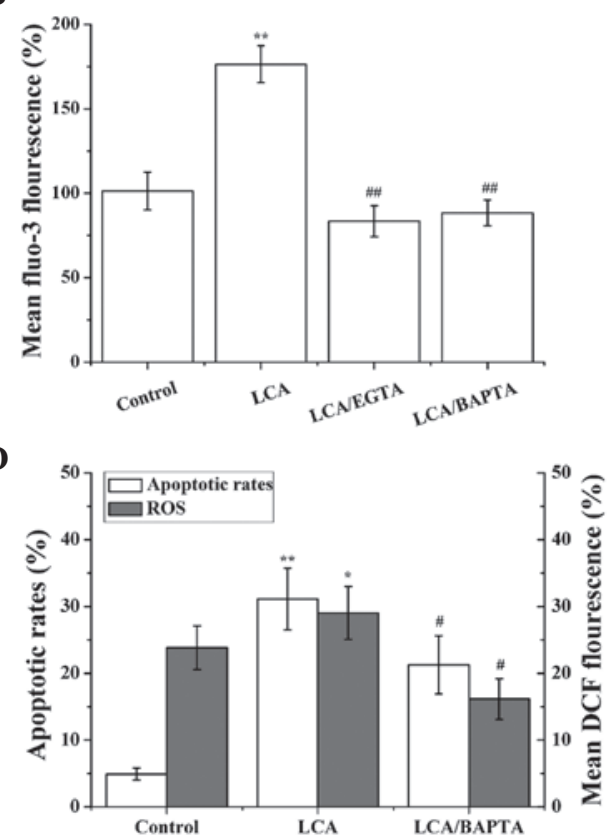

Figure 3. Licochalcone A (LCA) induced $\mathrm{Ca}^{2+}$ release and mitochondrial dysfunction in T24 cells. (A) Intracellular calcium fluorescent intensity following treatment with various concentrations of LCA. T24 cells were incubated with $0,20,40$ and $80 \mu \mathrm{M}$ LCA for $0.5,2,4$ and 8 h. Effects of ethylene glycol tetraacetic acid (EGTA and BAPTA-AM on (B) intracelluar $\mathrm{Ca}^{2+}$ levels and (C) apoptotic rate; T24 cells were pretreated for $24 \mathrm{~h}$ with LCA (55 $\left.\mu \mathrm{M}\right)$ followed by stimulation with EGTA $(200 \mu \mathrm{M})$ or BAPTA-AM $(10 \mu \mathrm{M})$. (D) Effects of BAPTA-AM on apoptotic rates and reactive oxygen species (ROS); T24 cells were pretreated for $24 \mathrm{~h}$ with LCA $(55 \mu \mathrm{M})$ followed by stimulation with BAPTA-AM $(10 \mu \mathrm{M})$. Data are presented as the mean \pm standard deviation of three separate experiments. ${ }^{*} \mathrm{P}<0.05,{ }^{* *} \mathrm{P}<0.01$ compared with the control group; ${ }^{\#} \mathrm{P}<0.05,{ }^{\# \#} \mathrm{P}<0.01$ compared with the LCA-treated group.

T24 cells were pretreated with BAPTA-AM, then treated with LCA for $1 \mathrm{~h}$, or the cells were treated with LCA alone. The levels of ROS generation were lower in the
LCA and BAPTA-AM treated group, as compared with in the LCA-treated group (apoptotic rates, $\mathrm{P}=0.0241$; ROS, $\mathrm{P}=0.0128$; Fig. 3D). These results suggest that BAPTA-AM 
A

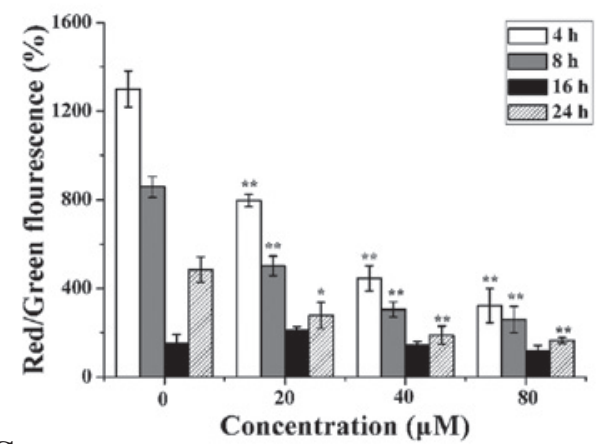

C

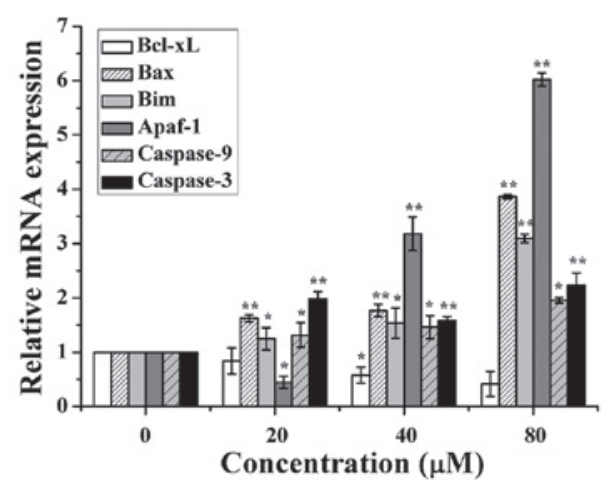

B

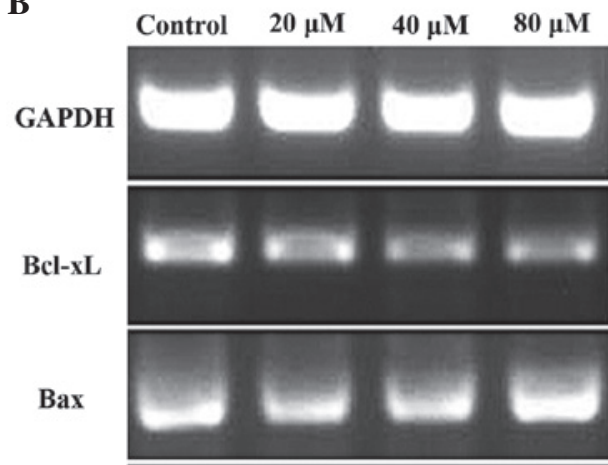

Bim

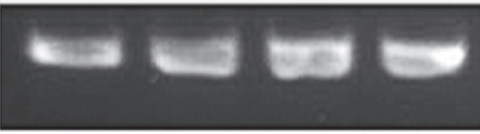

Apaf-1

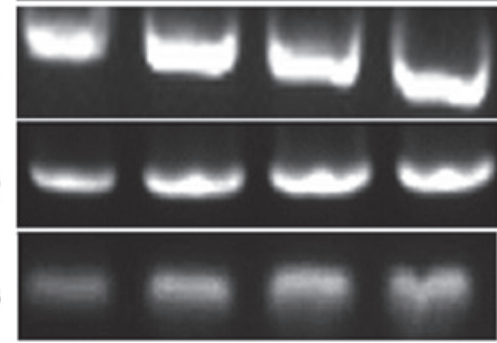

Figure 4. Licochalcone A (LCA) induced mitochondrial dysfunction in T24 cells. (A) T2 4 cells were incubated with $0,20,40$ and $80 \mu \mathrm{M} \mathrm{LCA}$ for $4,8,16$ and $24 \mathrm{~h}$, and the mitochondrial membrane potential was determined. The number of cells with normal polarized mitochondrial membranes (red) compared with the number of cells with depolarized mitochondrial membranes (green) is expressed as a percentage of the total cell number. (B) B-cell lymphoma (Bcl)-extra large (Bcl-xL), Bcl-2-associated X protein (Bax), Bcl-2-interacting mediator of cell death (Bim), apoptotic protease activating factor-1 (Apaf-1), caspase-9 and caspase-3 expression levels were detected by semiquantitative polymerase chain reaction (PCR) following treatment with $0,20,40$ and $80 \mu \mathrm{M} \mathrm{LCA}$ for $24 \mathrm{~h}$. (C) Changes in the mRNA expression levels of Bcl-xL, Bax, Bim, Apaf-1, caspase- 9 and caspase- 3 were examined by quantitative PCR analysis. T24 cells were incubated with 0 , 20, 40 and $80 \mu \mathrm{M}$ LCA for $24 \mathrm{~h}$. Data are presented as the mean \pm standard deviation of three separate experiments. ${ }^{*} \mathrm{P}<0.05,{ }^{* *} \mathrm{P}<0.01$ compared with the control group. GAPDH, glyceraldehyde 3-phosphate dehydrogenase.
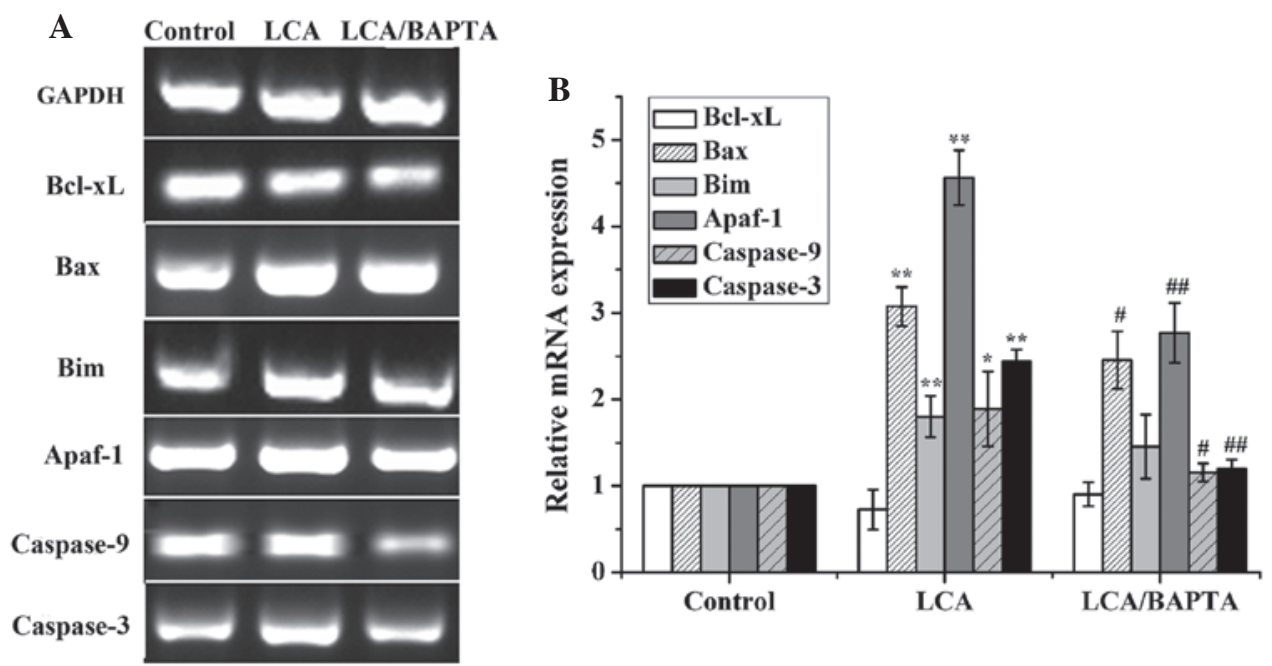

Figure 5. BAPTA-AM mediated the expression of mitochondrial apoptosis-associated genes. (A) B-cell lymphoma (Bcl)-extra large (Bcl-xL), Bcl-2-associated $\mathrm{X}$ protein (Bax), Bcl-2-interacting mediator of cell death (Bim), apoptotic protease activating factor-1 (Apaf-1), caspase-9 and caspase-3 expression levels were detected by semiquantitative polymerase chain reaction (PCR). (B) Changes in the mRNA expression levels of Bcl-xL, Bax, Bim, Apaf-1, caspase-9 and caspase- 3 were examined by quantitative PCR analysis. T24 cells were pretreated for $24 \mathrm{~h}$ with licochalone A (LCA; $55 \mu \mathrm{M}$ ) followed by stimulation with BAPTA-AM $(10 \mu \mathrm{M})$. Data are presented as the mean \pm standard deviation of three separate experiments. ${ }^{*} \mathrm{P}<0.05,{ }^{* *} \mathrm{P}<0.01$ compared with the control group; ${ }^{\#} \mathrm{P}<0.05,{ }^{\# \#} \mathrm{P}<0.01$ compared with the LCA-treated group. GAPDH, glyceraldehyde 3-phosphate dehydrogenase.

may decrease LCA-induced apoptosis and ROS generation, thus indicating that cytosolic $\mathrm{Ca}^{2+}$ release may act upstream of ROS generation in LCA-treated T24 cells.
Intracellular $\mathrm{Ca}^{2+}$ has a critical role in LCA-induced apoptosis of T24 cells. As shown in Fig. 4A, treatment of T24 cells with LCA for 4, 8, 16 and $24 \mathrm{~h}$ induced a time-dependent reduc- 


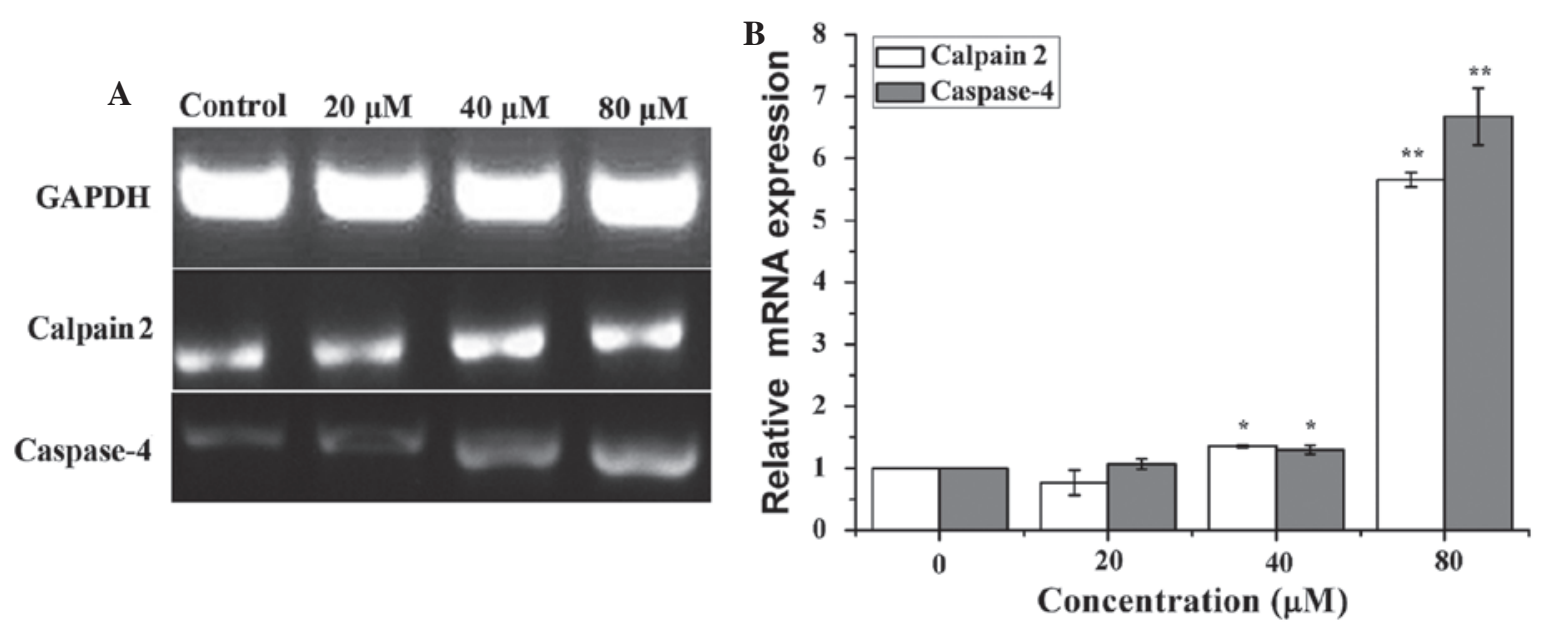

Figure 6. Licochalcone A (LCA) induced endoplasmic reticulum stress in T24 cells. (A) Calpain 2 and caspase-4 expression levels were detected by semiquantitative polymerase chain reaction (PCR). (B) Changes in the mRNA expression levels of calpain 2 and caspase- 4 were examined by quantitative PCR analysis. T24 cells were incubated with 0, 20, 40 and $80 \mu \mathrm{M} \mathrm{LCA}$ for $24 \mathrm{~h}$. Data are presented as the mean \pm standard deviation of three separate experiments. "P $<0.05$, ${ }^{* *} \mathrm{P}<0.01$ compared with the control group. GAPDH, glyceraldehyde 3-phosphate dehydrogenase.

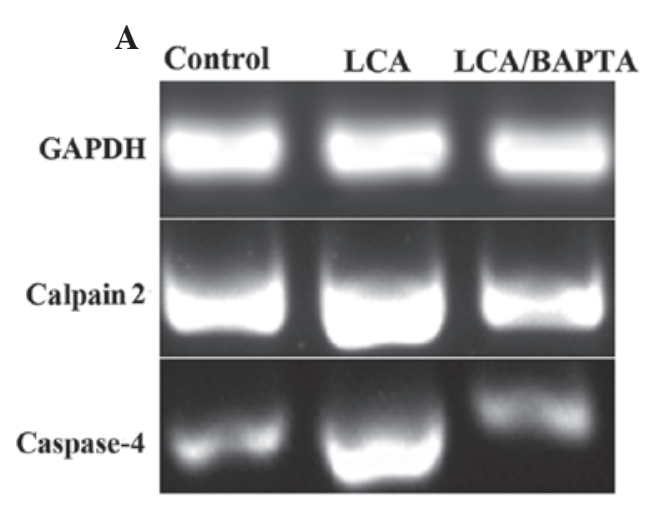

Figure 7. BAPTA-AM mediated the expression of genes involved with endoplasmic reticulum stress-associated apoptosis. (A) Calpain 2 and caspase-4 expression levels were detected by semiquantitative polymerase chain reaction (PCR). (B) Changes in the mRNA expression levels of calpain2 and caspase-4 were examined by quantitative PCR analysis. T2 4 cells were pretreated for $24 \mathrm{~h}$ with licochalcone A (LCA; $55 \mu \mathrm{M})$ followed by stimulation with BAPTA-AM $(10 \mu \mathrm{M})$. Data are presented as the mean \pm standard deviation of three separate experiments. ${ }^{*} \mathrm{P}<0.05,{ }^{* *} \mathrm{P}<0.01$ compared with the control group; ${ }^{*} \mathrm{P}<0.05$, ${ }^{\# \#} \mathrm{P}<0.01$ compared with the LCA-treated group. GAPDH, glyceraldehyde 3-phosphate dehydrogenase.

tion in MMP $\left(\mathrm{P}=6.0 \times 10^{-8}, \mathrm{P}=9.5 \times 10^{-7}, \mathrm{P}=0.0793, \mathrm{P}=1.1 \times 10^{-5}\right.$ respectively), thus suggesting that $\mathrm{LCA}$-induced cell apoptosis may be associated with mitochondrial dysfunction.

To further explore whether LCA induces apoptosis via the regulation of mitochondrial apoptosis-associated genes, B-cell lymphoma ( $\mathrm{Bcl})$-2-associated $\mathrm{X}$ protein (Bax), Bcl-2-interacting mediator of cell death (Bim), Bcl-extra large (xL), apoptotic protease activating factor-1 (Apaf-1), caspase- 9 and caspase- 3 were detected in T24 cells. The cells were treated with various concentrations of LCA for $24 \mathrm{~h}$. As shown in Fig. 4B and C, the mRNA expression levels of $\mathrm{Bcl}-\mathrm{xL}$ were downregulated $(\mathrm{P}=0.052)$, whereas Bax $\left(\mathrm{P}=4.1 \times 10^{-12}\right)$, Bim $\left(\mathrm{P}=2.4 \times 10^{-8}\right)$, Apaf-1 $\left(\mathrm{P}=1.8 \times 10^{-14}\right)$, caspase-9 $(\mathrm{P}=0.0107)$ and caspase-3 $(\mathrm{P}=0.0001)$ expression levels were upregulated in a concentration-dependent manner.

To determine whether intracellular $\mathrm{Ca}^{2+}$ levels exert a critical role on LCA-induced mitochondrial apoptosis,

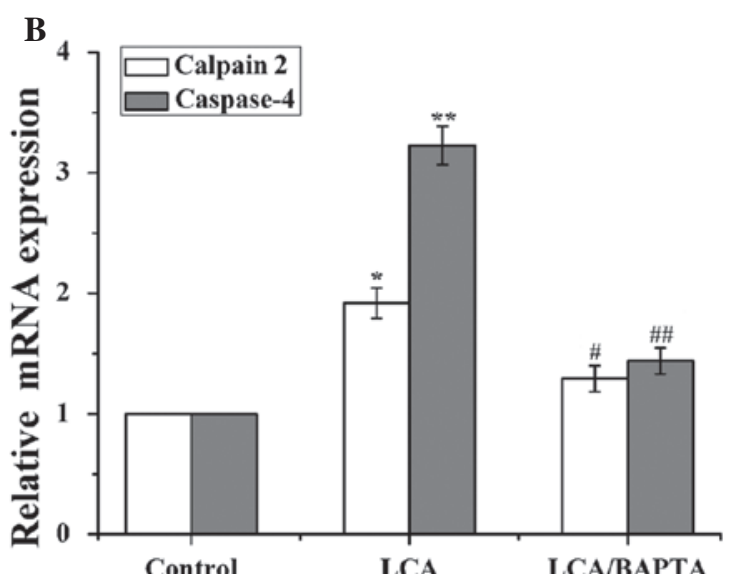

BAPTA-AM, an intracellular $\mathrm{Ca}^{2+}$ chelator, was used. T24 cells were treated with or without BAPTA-AM for $1 \mathrm{~h}$ prior to LCA treatment for $24 \mathrm{~h}$. As shown in Fig. 5, compared with the LCA-treated group, $\mathrm{Bax}(\mathrm{P}=0.0374)$, Apaf-1 $\left(\mathrm{P}=5.7 \times 10^{-5}\right)$, caspase-9 $(\mathrm{P}=0.0211)$ and caspase-3 $(\mathrm{P}=0.0095)$ expression were markedly downregulated. However, there was no significant difference in Bcl-xL mRNA expression between the LCA-treated and LCA + BAPTA-AM-treated groups. These data suggest that intracellular $\mathrm{Ca}^{2+}$ has a critical role in mitochondrial apoptosis.

LCA induces apoptosis via the ER stress pathway in T24 cells. The involvement of ER stress signaling in the responses triggered by LCA-induced apoptosis was evaluated based on the expression of calpain 2 and caspase-4. As shown in Fig. 6, cells were treated with LCA for $24 \mathrm{~h}$, and calpain 2 and caspase- 4 expression levels were increased in a concentration-dependent manner. Subsequently, the T24 cells were treated with or 
without BAPTA-AM for $1 \mathrm{~h}$ prior to LCA treatment for $24 \mathrm{~h}$, As shown in Fig. 7, compared with the LCA-treated group, calpain $2(\mathrm{P}=0.0418)$ and caspase- $4\left(\mathrm{P}=3.8 \times 10^{-5}\right)$ expression levels were downregulated in response to BAPTA-AM treatment. These results suggest that $\mathrm{Ca}^{2+}$ is involved in the ER stress-related apoptotic pathway.

\section{Discussion}

LCA has been reported to inhibit proliferation and induce apoptosis in various cancer cells, including MCF-7 human breast cancer cells (30) and colon cancer cells (22). We previously reported that LCA induced an increase in cytoplasmic ROS levels, by sensing inner mitochondrial ROS production, and activated caspase-3/caspase-9-mediated mitochondrial apoptotic signaling pathways (31). The present study demonstrated that: i) LCA induced $\mathrm{Ca}^{2+}$ release in $\mathrm{T} 24$ human bladder cancer cells; ii) LCA predominantly induced an increase in intracellular $\mathrm{Ca}^{2+}$ release to promote apoptosis; iii) intracellular $\mathrm{Ca}^{2+}$ may cause upstream ROS accumulation in LCA-treated T24 cells; iv) increased intracellular $\mathrm{Ca}^{2+}$ levels are involved in LCA-induced T2 4 cell apoptosis via mitochondrial dysfunction and the ER stress-related pathway. The mechanism by which LCA induces apoptosis may be mediated through increased levels of intracellular $\mathrm{Ca}^{2+}$. Notably, LCA enhanced intracellular $\mathrm{Ca}^{2+}$, induced mitochondrial dysfunction, and activated the apoptotic cascade and ER stress in T24 cells. These findings indicated that intracellular $\mathrm{Ca}^{2+}$ may have a prominent role in LCA-induced T24 cell apoptosis via he mitochondria-dependent and ER stress-activated apoptotic signals.

It has been indicated that increased $\mathrm{Ca}^{2+}$ levels may be associated with the apoptotic process (32). Apoptosis is often accompanied by increased $\mathrm{Ca}^{2+}$ levels, and the addition of calcium regulators or calmodulin inhibitors can directly induce apoptosis. These results suggested that apoptosis is closely associated with intracellular $\mathrm{Ca}^{2+}$ (33). In the present study, LCA induced apoptosis by the release of intracellular $\mathrm{Ca}^{2+}$, but not extracellular $\mathrm{Ca}^{2+}$, thus suggesting that intracellular $\mathrm{Ca}^{2+}$ is closely associated with apoptosis in T24 cells. Our previous study demonstrated that LCA inhibited proliferation by inducing ROS production in T24 cells (31). The present study demonstrated that when intracellular $\mathrm{Ca}^{2+}$ was inhibited, LCA-induced apoptosis and ROS generation were suppressed. These results indicated that $\mathrm{Ca}^{2+}$ may act upstream of ROS generation in T24 cells (Fig. 3).

Mitochondria have been demonstrated to have a crucial role in cell apoptosis, and the mitochondria-dependent apoptotic pathway is involved in LCA-induced apoptosis (7). The present study examined whether apoptosis is mediated through mitochondrial dysfunction, and the MMP was analyzed using the mitochondrion-sensitive dye JC-1. The results indicated that LCA was capable of inducing T24 cell apoptosis by decreasing MMP (Fig. 4A). In addition, mitochondrial apoptosis-related genes Bax, Bim, Apaf-1, caspase-9 and caspase-3 were activated by LCA, whereas Bcl-xL was inhibited. These data suggested that LCA induced apoptosis through mitochondrial dysfunction (Fig. 4B and C). Furthermore, when intracellular $\mathrm{Ca}^{2+}$ levels were decreased, Bax, Bim, Apaf-1 caspase- 9 and caspase-3 expression levels were inhibited, whereas Bcl-xL expression was not altered. These results indicated that it was the increased levels of $\mathrm{Ca}^{2+}$ that regulated the LCA-induced mitochondrial apoptotic pathway (Fig. 5).

Calpain is necessary for reconstruction of the cytoskeleton, intracellular signal transduction, regulation of the cell cycle, and apoptosis. Previous studies have reported that high cellular concentrations of $\mathrm{Ca}^{2+}$ can activate m-calpain, which can subsequently activate caspase-4, thus inducing the caspase cascade reaction and leading to ER stress-associated apoptosis (34-36). The present study, as expected, demonstrated that treatment of T24 cells with LCA induced an upregulation in the expression levels of calpain 2 and caspase-4. Conversely, calpain 2 and caspase- 4 expression levels were reduced alongside a reduction in the concentration of $\mathrm{Ca}^{2+}$. These findings indicated that intracellular $\mathrm{Ca}^{2+}$ is associated with LCA-induced ER stress-associated apoptosis in T24 cells (Figs. 6 and 7).

In conclusion, the present study demonstrated that LCA induces apoptosis in T24 cells, and its mechanism may be associated with an intracellular imbalance in calcium homeostasis. LCA was able to induce intracellular $\mathrm{Ca}^{2+}$ release, promote ROS accumulation, and regulate the expression of mitochondrial apoptosis-related genes (Bax, Bim, Apaf-1, caspase-9 and caspase-3 expression) and ER stress-induced apoptosis-related genes (calpain 2 and caspase-4), thus resulting in apoptosis. These data provide further support for the notion that LCA should be further explored as a possible chemopreventive modality, as well as in terms of its possible effectiveness in the treatment of bladder cancer.

\section{Acknowledgements}

The present study was supported by the National Natural Science Foundation of China (grant nos. 31471338 and 81260338), the Science and Technology project of Shihezi City, and the Xinjiang Production and Construction Corps Funds for Innovation Team in Key Areas (to Q.S. Zheng).

\section{References}

1. Wang X, Feng Y, Wang N, Cheung F, Tan HY, Zhong S, Li C and Kobayashi S: Chinese medicines induce cell death: The molecular and cellular mechanisms for cancer therapy. Biomed Res Int 2014: 530342, 2014.

2. Lu C and Mei X: Study on anti-tumor activity of extracts from cultured cells of Taxus chinensis. Zhong Yao Cai 26: 335-337, 2003 (In Chinese).

3. Wang Q, Du H, Geng G, Zhou H, Xu M, Cao H, Zhang B, Song G and $\mathrm{Hu}$ T: Matrine inhibits proliferation and induces apoptosis via BID-mediated mitochondrial pathway in esophageal cancer cells. Mol Biol Rep 41: 3009-3020, 2014.

4. Zhao H, Jiang JT and Zheng QS: Advance in studies on pharmacological effects of licochalcone A. Zhongguo Zhong Yao Za Zhi 38: 3814-3818, 2013 (In Chinese).

5. Fukai T, Marumo A, Kaitou K, Kanda T, Terada S and Nomura T: Anti-Helicobacter pylori flavonoids from licorice extract. Life Sci 71: 1449-1463, 2002.

6. Funakoshi-Tago M, Nakamura K, Tsuruya K, Hatanaka M, Mashino T, Sonoda Y and Kasahara T: The fixed structure of Licochalcone A by alpha, beta-unsaturated ketone is necessary for anti-inflammatory activity through the inhibition of NF-kappaB activation. Int Immunopharmacol 10: 562-571, 2010.

7. Xiao XY, Hao M, Yang XY, Ba Q, Li M, Ni SJ, Wang LS and Du X: Licochalcone A inhibits growth of gastric cancer cells by arresting cell cycle progression and inducing apoptosis. Cancer Lett 302: 69-75, 2011. 
8. Zheng Q and Ye M: Chemical analysis of Chinese herbal medicine Gan-Cao (licorice). J Chromatogr A 1216: 1954-1969, 2009.

9. Feldman $M$ and Grenier D: Cranberry proanthocyanidins act in synergy with licochalcone A to reduce Porphyromonas gingivalis growth and virulence properties, and to suppress cytokine secretion by macrophages. J Appl Microbiol 113: 438-447, 2012.

10. Messier C and Grenier D: Effect of licorice compounds licochalcone A, glabridin and glycyrrhizic acid on growth and virulence properties of Candida albicans. Mycoses 54: e801-e806, 2011.

11. Furusawa J, Funakoshi-Tago M, Mashino T, Tago K, Inoue H, Sonoda Y and Kasahara T: Glycyrrhiza inflata-derived chalcones, Licochalcone A, Licochalcone B and Licochalcone D, inhibit phosphorylation of NF-kappaB p65 in LPS signaling pathway. Int Immunopharmacol 9: 499-507, 2009.

12. Lee CS, Kwak SW, Kim YJ, Lee SA, Park ES, Myung SC, Kim W, Lee MS and Lee JJ: Guanylate cyclase activator YC-1 potentiates apoptotic effect of licochalcone A on human epithelial ovarian carcinoma cells via activation of death receptor and mitochondrial pathways. Eur J Pharmacol 683: $54-62,2012$

13. Kerr JF, Wyllie AH and Currie AR: Apoptosis: A basic biological phenomenon with wide-ranging implications in tissue kinetics. Br J Cancer 26: 239-257, 1972.

14. Zamzami N, Marchetti P, Castedo M, Decaudin D, Macho A, Hirsch T, Susin SA, Petit PX, Mignotte B and Kroemer G: Sequential reduction of mitochondrial transmembrane potential and generation of reactive oxygen species in early programmed cell death. J Exp Med 182: 367-377, 1995.

15. Kim J, Choi TG, Ding Y, Kim Y, Ha KS, Lee KH, Kang I, Ha J, Kaufman RJ, Lee J, et al: Overexpressed cyclophilin B suppresses apoptosis associated with ROS and $\mathrm{Ca}^{2+}$ homeostasis after ER stress. J Cell Sci 121: 3636-3648, 2008.

16. Santos CX, Tanaka LY, Wosniak J and Laurindo FR: Mechanisms and implications of reactive oxygen species generation during the unfolded protein response: Roles of endoplasmic reticulum oxidoreductases, mitochondrial electron transport, and NADPH oxidase. Antioxid Redox Signal 11: 2409-2427, 2009

17. Yan Y, Wei CL, Zhang WR, Cheng HP and Liu J: Cross-talk between calcium and reactive oxygen species signaling. Acta Pharmacol Sin 27: 821-826, 2006.

18. Berridge MJ, Lipp P and Bootman MD: The versatility and universality of calcium signalling. Nat Rev Mol Cell Biol 1 : $11-21,2000$

19. Nakagawa T and Yuan J: Cross-talk between two cysteine protease families. Activation of caspase-12 by calpain in apoptosis. J Cell Biol 150: 887-894, 2000.

20. Martinez JA, Zhang Z, Svetlov SI, Hayes RL, Wang KK and Larner SF: Calpain and caspase processing of caspase-12 contribute to the ER stress-induced cell death pathway in differentiated PC12 cells. Apoptosis 15: 1480-1493, 2010.

21. Tan Y, Dourdin N, Wu C, De Veyra T, Elce JS and Greer PA: Ubiquitous calpains promote caspase-12 and JNK activation during endoplasmic reticulum stress-induced apoptosis. J Biol Chem 281: 16016-16024, 2006.
22. Choi AY, Choi JH, Hwang KY, Jeong YJ, Choe W, Yoon KS, Ha J, Kim SS, Youn JH, Yeo EJ and Kang I: Licochalcone A induces apoptosis through endoplasmic reticulum stress via a phospholipase $\mathrm{C} \gamma 1-, \mathrm{Ca}(2+)-$, and reactive oxygen species-dependent pathway in HepG2 human hepatocellular carcinoma cells. Apoptosis 19: 682-697, 2014.

23. Yuan X, Li D, Zhao H, Jiang J, Wang P, Ma X, Sun X and Zheng Q: Licochalcone A-induced human bladder cancer T24 cells apoptosis triggered by mitochondria dysfunction and endoplasmic reticulum stress. Biomed Res Int 2013: 474272, 2013.

24. Skehan P, Storeng R, Scudiero D, Monks A, McMahon J, Vistica D, Warren JT, Bokesch H, Kenney S and Boyd MR: New colorimetric cytotoxicity assay for anticancer-drug screening. J Natl Cancer Inst 82: 1107-1112, 1990.

25. Hockenbery D, Nuñez G, Milliman C, Schreiber RD and Korsmeyer SJ: Bcl-2 is an inner mitochondrial membrane protein that blocks programmed cell death. Nature 348 : 334-346, 1990

26. Jung JI, Lim SS, Choi HJ, Cho HJ, Shin HK, Kim EJ, Chung WY, Park KK and Park JH: Isoliquiritigenin induces apoptosis by depolarizing mitochondrial membranes in prostate cancer cells. J Nutr Biochem 17: 689-696, 2006.

27. Vanden Hoek TL, Li C, Shao Z, Schumacker PT and Becker LB: Significant levels of oxidants are generated by isolated cardiomyocytes during ischemia prior to reperfusion. J Mol Cell Cardiol 29: 2571-2583, 1997.

28. Reers M, Smith TW and Chen LB: J-aggregate formation of a carbocyanine as a quantitative fluorescent indicator of membrane potential. Biochemistry 30: 4480-4486, 1991.

29. Carthagena L, Bergamaschi A, Luna JM, David A, Uchil PD, Margottin-Goguet F, Mothes W, Hazan U, Transy C, Pancino G and Nisole S: Human TRIM gene expression in response to interferons. PLoS One 4: e4894, 2009.

30. Rafi MM, Vastano BC, Zhu N, Ho CT, Ghai G, Rosen RT, Gallo MA and DiPaola RS: Novel polyphenol molecule isolated from licorice root (Glycyrrhiza glabra) induces apoptosis, G2/M cell cycle arrest, and Bcl-2 phosphorylation in tumor cell lines. J Agric Food Chem 50: 677-684, 2002.

31. Jiang J, Yuan X, Zhao H, Yan X, Sun X and Zheng Q: Licochalcone A inhibiting proliferation of bladder cancer T24 cells by inducing reactive oxygen species production. Biomed Mater Eng 24: 1019-1025, 2014.

32. Kaiser N and Edelman IS: Calcium dependence of glucocorticoid-induced lymphocytolysis. Proc Natl Acad Sci USA 74: 638-642, 1977

33. McConkey DJ and Orrenius S: The role of calcium in the regulation of apoptosis. Biochem Biophys Res Commun 239: 357-366, 1997.

34. Sergeev IN: Calcium as a mediator of 1,25-dihydroxyvitamin D3-induced apoptosis. J Steroid Biochem Mol Biol 89-90: 419-425, 2004.

35. Mekahli D, Bultynck G, Parys JB, De Smedt H and Missiaen L: Endoplasmic-reticulum calcium depletion and disease. Cold Spring Harb Perspect Biol 3: a004317, 2011.

36. Matsuzaki S, Hiratsuka T, Kuwahara R, Katayama T and Tohyama M. Caspase- 4 is partially cleaved by calpain via the impairment of $\mathrm{Ca} 2+$ homeostasis under the ER stress. Neurochem Int 56: 352-356, 2010. 